\title{
Hibernation Records on the Incisor Surface in the Turkish Hamster (Mesocricetus brandti) (Rodentia, Cricetidae)
}

Elena A. Zaytseva ${ }^{1}$, https://orcid.org/0000-0002-1974-4988; zaycevaolena@gmail.com

Magomed M. Chunkov ${ }^{2}$, https://orcid.org/0000-0002-5950-9069; chunkov@mail.ru

Kamil Z. Omarov ${ }^{2}$, https://orcid.org/0000-0001-6354-920X; omarovkz@mail.ru

\author{
${ }^{1}$ A. N. Severtsov Institute of Ecology and Evolution, Russian Academy of Sciences \\ 33 Leninsky Prosp., Moscow 119071, Russia \\ ${ }^{2}$ Precaspian Institute of Biological Resources \\ of the Dagestan Federal Research Centre of the Russian Academy of Sciences \\ 45 M. Gadzhiev St., Makhachkala 367000, Russia
}

Received 28 June 2019, revised 14 July 2019, accepted 16 August 2019

\begin{abstract}
Zaytseva E. A., Chunkov M. M., Omarov K. Z. Hibernation Records on the Incisor Surface in the Turkish Hamster (Mesocricetus brandti) (Rodentia, Cricetidae). Povolzhskiy Journal of Ecology, 2020, no. 1, pp. 44 - 51. DOI: https://doi.org/10.35885/1684-7318-2020-1-44-51
\end{abstract}

This article is an open access article distributed under the terms and conditions of the Creative Commons Attribution 4.0 License

\begin{abstract}
The teeth of an adult female of the Turkish hamster (Mesocricetus brandti) after hibernation in semi-natural conditions were examined to reveal a relationship between the hibernation pattern on the incisor surface and the data of a temperature logger. The female spent the winter in a burrow prepared by herself inside a wintering cage from October 2018 till May 2019. A temperature logger was implanted to the animal intraperitoneally to record body temperature at 20-min intervals. Regular bouts of hypothermia started in mid-October. The longevity of each hypothermia bout increased whereas the minimum body temperature decreased and reached its lowest value in March. Later, the process proceeded backwards until the end of the heterothermia period. In the apical region of the incisor, daily increments were wide and well-distinguished which indicates that they had formed before the onset of the heterothermal period. In the basal region, closer to the growth zone, the increments were narrow and distinct, and their number corresponded in general to the number of normothermia episodes bouts. At the very base of the incisor as well as at its apical part, typical daily increments were revealed again. However, no correlation between the longevity of normothermia bouts and the width of increments was found. These data varied greatly from two other hamsters. In the Ciscaucasian hamster (Mesocricetus raddei) the number and character of increments comply with the number and duration of normothermia bouts, in the Common hamster (Cricetus cricetus), the "hibernation zone" was not recorded on the incisor surface. The Turkish hamster demonstrate an intermediate pattern, which we explain by quite different hibernation conditions of these species.

Keywords: hypothermia, Mesocricetus brandti, incisor increments, temperature logger.
\end{abstract}

DOI: https://doi.org/10.35885/1684-7318-2020-1-44-51

\section{INTRODUCTION}

In rodents, the daily dentin layers are formed on the incisor surface. That may reflect variable events in ontogenesis including hibernation. (Klevezal, Mina, 1990; Klevezal, Sukhovskaya, 1995). "Hibernation record" is a series of narrow and well-defined 


\section{HIBERNATION RECORDS ON THE INCISOR SURFACE}

increments within the "hibernation zone", unlike the wider daily increments. This phenomenon has been described for many hibernating rodents (Rinaldi, 1999; Goodwin, Ryckman, 2006; Klevezal, Lobkov, 2008; Klevezal, Shchepotkin, 2012).

Many researchers of hibernation use the method of intraperitoneal implanting of a temperature logger under both natural and laboratory conditions. The logger registers body temperature throughout the whole hibernation. Therefore, a unique chance to compare the character of hibernation and its record on the incisor surface is given. However, the possibility to obtain incisors just after the end of hibernation is not frequent. Additionally, incisors of rodents are subjected to continual growth to compensate for their continuous grinding. The incisor of the hamster is entirely renewed during 1-2 months (Klevezal, 2010); for this reason, it is necessary to obtain teeth before grinding the region with hibernation increments.

As it was mentioned above, simultaneous obtaining of the temperature records during hibernation and incisors with notable increments is very rarely possible. Such studies were made for several species of subfamily Cricetidae. Thus, it was shown for the Ciscaucasian hamster (Mesocricetus raddei), that the width of increments within the "hibernation zone" correlates with the duration of normothermia bouts (Klevezal et al., 2012, 2018). These data differ from the data obtained for the Eversmann's hamster ( $\mathrm{Al}$ locricetulus eversmanni) in which the correlation between the number of narrow increments on the incisor surface and the number of normothermia bouts within the "hibernation zone" was not found (Klevezal et al., 2015). Studies of teeth in the Common hamster (Cricetus cricetus) revealed that daily increments are well-defined on the incisor surface, but they cannot be found in the "hibernation zone" (Klevezal et al., 2020).

For the Turkish hamster (Mesocricetus brandti) reared in the laboratory, the record of hibernation on the surface of incisors has been described earlier (Batavia et al., 2013). The authors pointed out the influence of photoperiod on the readability of daily increments. However, they did not compare the increments character to changes in body temperature, but only supported the presence of "hibernation records" on the incisor surface. In our study, we are trying to fill up this gap, comparing "hibernation record" on the incisor with the dynamics of body temperature in this species under semi-natural conditions.

The species belong to the genus Mesocricetus are typical representatives of E. Mediterranean steppe fauna. The Turkish hamster has the largest range among all other Mesocricetus species. It includes the Republic of Turkey, Transcaucasia (Armenia, Georgia, Azerbaijan), and N-E Iran. This species inhabits arid and semi-arid steppe zones in lowlands and mountains to an altitude of $2500 \mathrm{~m}$ (Dogramaci et al., 1994; Yigit et al., 2006; Neumann et al., 2017). An isolated population of this species was found in the Republic of Dagestan (Russian Federation) (Pavlinov et al., 2002).

\section{MATERIAL AND METHODS}

The mature female of the Turkish hamster was caught close to village Urma in Levashinski District (42 $\left.30^{\prime} 39^{\prime \prime} \mathrm{N}, 47^{\circ} 17^{\prime} 48^{\prime \prime} \mathrm{E}\right)$ (the Republic of Dagestan) on June 20, 2018, and was moved to village Khunzakh of the Khunzakh District $\left(42^{\circ} 33^{\prime} 00^{\prime \prime}\right.$ N, $46^{\circ} 45^{\prime} 00^{\prime \prime} \mathrm{E}$ ), where the experiment was performed. To register the body temperature, a logger DTN3-28 (EMBI RESEARCH, Novosibirsk) (Petrovskii et al., 2008) was im- 
planted peritoneally. The temperature was registered every 20 th minute. On October 5 , 2018, the hamster was transferred into the cage $1 \times 1 \mathrm{~m}$ and $1.3 \mathrm{~m} \mathrm{high}$, earthed for $1 \mathrm{~m}$ deep. A food supply (vegetables and a mixture of grain and sunflower seeds) was put inside the cage. The animal dug a wintering burrow in the soil to the depth of $80-90 \mathrm{~cm}$, stored there enough food, and safely spent the winter inside the burrow. In early May, the female was caught and slaughtered, the logger was withdrawn from the peritoneal cavity and decoded.

Lower incisors were removed from the cranium, cleaned, and studied under the microscope Leica StereoZoom 6 Photo $\left(2-4^{\times}\right)$. The illumination angle was adjusted by such a way that the relief of the incisor surface was revealed most clearly. The photos were made with a digital camera Nikon Colpix 4500, in some cases, with digital microscope VHX-1000 with an objective lens VH-Z 100 UP.

For all measurements, the program Adobe Photoshop CS6 (with the measurement error about $6 \%$ ) was used. We revealed that changes in the illumination angle alters the luminance of increment zones but does not alter their real width. For lower incisors, there is a possibility for some measurement error connected with the distance of the measured place from the tooth edge because of the tooth curvature. It may be as large as $12-13 \%$ (Klevezal, 2010). To minimize this error, the measurements were made at the same distance from the tooth edge and repeated three times with the mean values to be used further. The data from the logger were read off and processed with the use of software Ecologger 2.3 and Microsoft Excel 2010.

Terminology. The region of the incisor located in the alveolus we call the basal part (Fig. 1), and the exposed region - the apical part (Fig. 2). During tooth growth, the daily increments form regular elevations or folds. These folds are formed due to the uneven

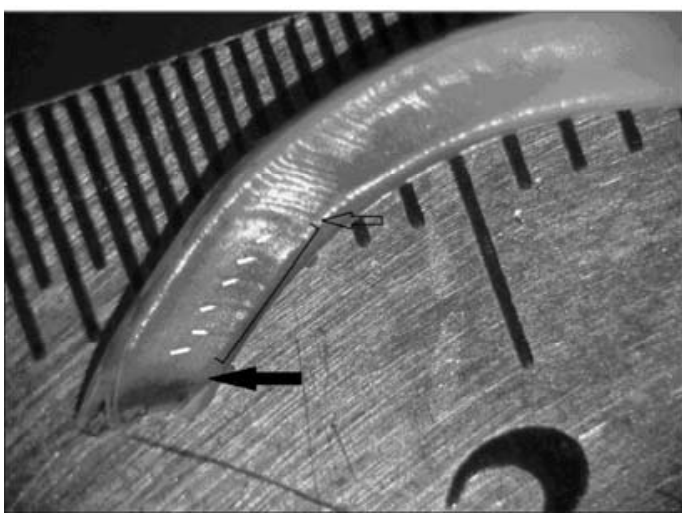

Fig. 1. Basal part of incisor of Turkish hamster, digital microscope. An empty arrowhead indicates the end of a zone with narrow distinct increments formed during the hibernation period. White arrowheads indicate boundaries of increments, formed after the end of the hibernation period. Black solid arrowhead points at a region without notable increments growth of different tissues, and the incisor extrudes from the alveolus (Klevezal, Shchepotkin, 2017). The increments might be visible (with distinct boundaries), which are easy to count, or being unclear. They might be even (uniform) if the width of adjacent increments is similar, or uneven (nonuniform) if they are of different width. The increments may be simple or complex (if the increment subdivides into several, mostly two, increments).

The term heterothermy period is a synonym for hibernation. It is taken from the first drop of body temperature below $+35^{\circ} \mathrm{C}$ to the moment when under periodic temperature fluctuations $+35^{\circ} \mathrm{C}$ again becomes the lowest temperature. Heterothermy 
period consists of bouts of hypothermia - the period started when body temperature decreases below $+35^{\circ} \mathrm{C}$ and finished when it increases up to normal $\left(+35 \ldots+38^{\circ} \mathrm{C}\right)$, and bouts of normothermia - the period between neighbor hypothermia episodes.

\section{RESULTS AND DISCUSSION}

According to the data of temperature registration (Fig. 3), the first hypothermia bout took place on October 16, 2018, and then, till April 2019, more 24 episodes occur. Before that, the body temperature fluctuated between +34 and $+37^{\circ} \mathrm{C}$. The first four bouts did not exceed three days with body temperature from +12 to $+16^{\circ} \mathrm{C}$. In early October, the duration of bouts increased up to 190 hours (almost 8 days). In November 5, bouts were registered with the longest continuing 147 hours, and the lowest body temperature being $+4^{\circ} \mathrm{C}$. In December there were three bouts of hypothermia; each of them lasted more than 150 hours, and the lowest body temperature was $+3^{\circ} \mathrm{C}$. During January and February six bouts were registered, their duration increased to 240 hours. In March, the longest ones, in about 265 hours was recorded, and then the duration of such periods

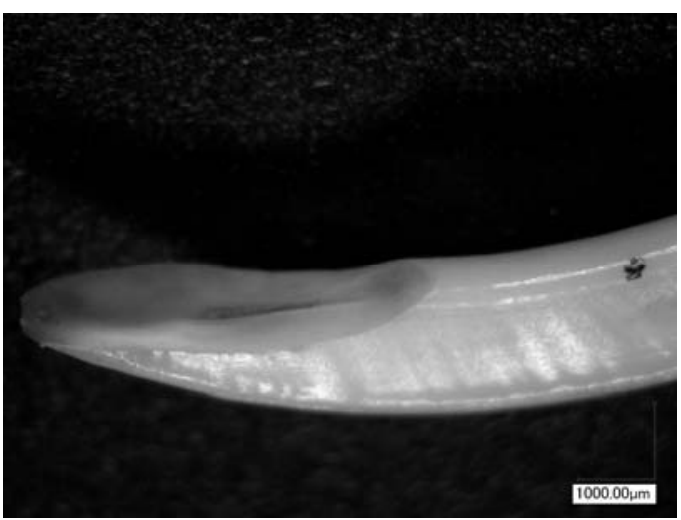

Fig. 2. Apical part of the incisor of Turkish hamster (digital microscope). Increments on the incisor surface, formed before hibernation started to decrease. The last bout occurred on April 25. Every bout of hypothermia was interrupted by a normothermic period. These periods were of variable length - in October and November, they lasted 20-26 hours, during winter months - by less than 10 hours, in spring - up to 14 hours (Fig. 4).

On the incisor surface, very distinct, narrow increments were observed in the basal part of the tooth (Fig. 1), and within the apical part, increments were less discrete (Fig. 2). According to the temperature registration device, the last hypothermia bout ended on April 25, 2019, and the temperature logger was withdrawn on May 4, i.e. 9 days later (Fig. 3). We expected to see

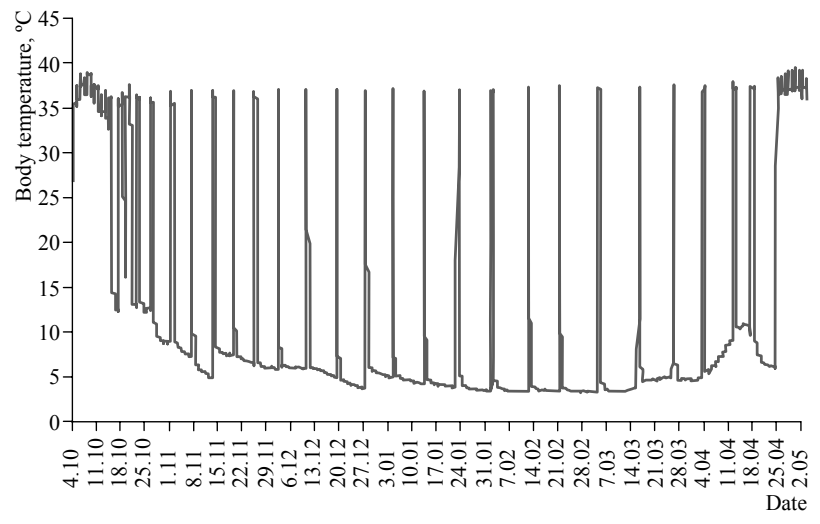

Fig. 3. Temperature record of hibernation period of the Turkish hamster 
about 9 wide increments on the very basal section of the tooth. Because we had no precise reference point, we tried to reconstruct it by comparing increments character with the time of the last bout. On the basal section of the tooth, starting from the series of narrow distinct increments and proceeding basally, one can see 2 less distinct complex incre-

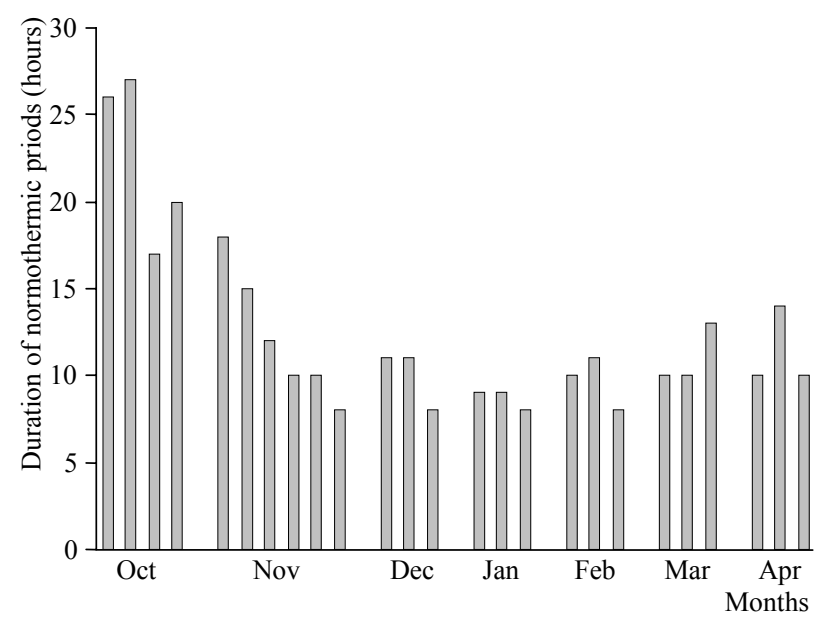

Fig. 4. Duration of normothermic periods (hours) in the Turkish hamster ments, then 4 more precise even wide increments, and the section without visible increments (Fig. 1). But knowing an average width of six described increments one can suppose that there is a place for more 3 increments on the basal section of the tooth. Such supposition is possible taking into consideration that the most basal section of the incisor (adjacent to the growth zone) is soft and can be easily deformed. Thus, within this part of incisor, there are 9 increments similar by width with increments within its most apical section, developed before the period of heterothermia (marked by numerous narrow increments). In this way, we obtained the full "hibernation record" on the incisors of the female, supported by the temperature curve.

According to the thermal record, during the hibernation period, the animal experienced 26 bouts of hypothermia interrupted by 25 episodes of normothermia, during which the formation of increments took place, i.e., we expected to find out 25 narrow distinct increments. Indeed, the number of visible increments within the "hibernation zone" was 24; it approximately corresponds to the number of bouts of normothermia. These are seven narrow, precise uniform increments by $145 \mu \mathrm{m}$ each, then two unclear narrow increments by $92 \mu \mathrm{m}$, then two wide complex (double) increments: the first pair by $185 \mu \mathrm{m}$, the second - by $172 \mu \mathrm{m}$. Then follow five unclear uniform increments by $153 \mu \mathrm{m}$, later - two more unclear increments by 130 and $160 \mu \mathrm{m}$, then follow the region with three unclear increments close to each other by $165 \mu \mathrm{m}$, and one wide unclear increment $321 \mu \mathrm{m}$ long.

In that way, as a result of our study, an agreement between the number of narrow increments on incisor of Turkish hamster and the number of episodes of normothermia has been established, but no concordance between the increment width and duration of normothermic bouts was found (Fig. 4, 5). Earlier, during a similar study on Ciscaucasian hamster, the width of increments has corresponded to the duration of normothermic period (Klevezal et al., 2012; Klevezal et al., 2018). As has been noted above, in the Common hamster, despite the presence of well-defined alternation of periods of normoand hypothermia on the temperature record, the "hibernation zone" is seldom recorded 
(Klevezal et al., 2020). Possibly, the last species, unlike the Turkish hamster, has much shorter (up to 6 days) and irregular periods of hypothermia. At the same time, the duration of normothermia bouts usually does not exceed 24 hours. During arousals, the Common hamster goes out of its burrow and feeds (Surov et al., 2019). It is established neither for the Turkish nor for Ciscaucasian hamsters. Differences in hibernation patterns between these two hamsters also include body temperature at hypothermia, which may decrease to $1^{\circ} \mathrm{C}$ in the Ciscaucasian hamster, and only to $3.4^{\circ} \mathrm{C}$ in the Turkish hamster. Differences in "hibernation records" between these species also may be determined by different environmental conditions during hibernation in Dages-

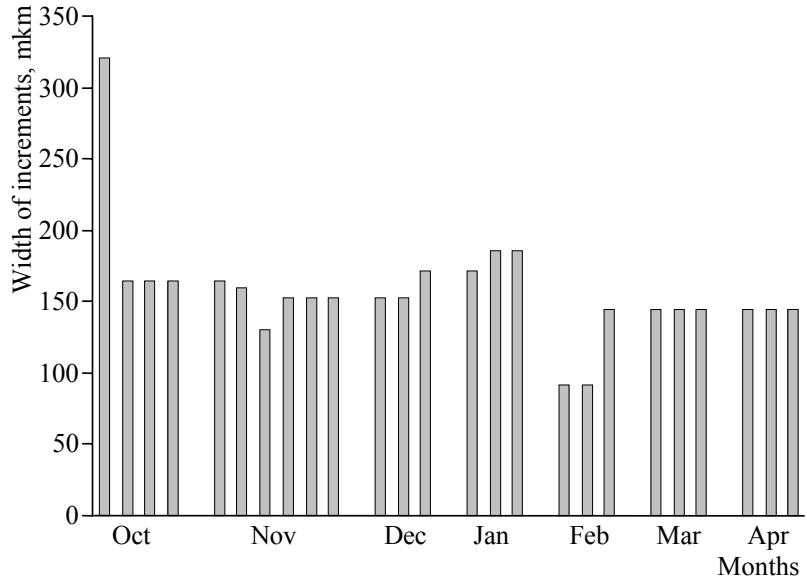

Fig. 5. Width of increments on the basal part of incisor of the Turkish hamster tan. The Turkish hamster resides at the altitude of $1400 \mathrm{~m}$ a.s.l., while the Ciscaucasian hamster - at about $2000 \mathrm{~m}$. Accordingly, foraging conditions after the hibernation period and possibilities of food caching in autumn also differ.

Summing up all preceding, we suppose that the presence of "hibernation record" on incisors of various rodents (or its absence) depends on the possibility of foraging inside or outside the burrow during hibernation period, and on the type and amount of food stored, which may be used during arousals.

\section{Acknowledgments}

We are grateful to Dr. Galina A. Klevezal and Dr. Dmitry V. Shchepotkin from Kol'tsov Institute of Developmental Biology, Russian Academy of Sciences, for their comments on the text, helping with photos and teaching by methods. We are grateful to Dr. Alexey V. Surov from Severtsov Institute of Ecology and Evolution, Russian Academy of Sciences, for his comments on the text.

\section{REFERENCES}

Batavia M., Nguyen G., Zucker I. The Effects of Day Length, Hibernation, and Ambient Temperature on Incisor Dentin in the Turkish hamster (Mesocricetus brandti). J. of Comparative Physiology B, 2013, vol. 183, iss. 4, pp. 557-566.

Dogramaci S., Kefelioglu H., Gündüz I. Karyological Analysis of the Species of Mesocricetus (Mammalia, Rodentia) in Anatolia. Turkish J. of Zoology, 1994, vol. 18, no. 1, pp. 41-45.

Goodwin H. T., Ryckman E. M. Lower Incisors of Prairie Dogs (Cynomys) as Biorecorders of Hibernation and Season of Death. J. of Mammalogy, 2006, vol. 87, no. 5, pp. 1002-1012. 


\section{E. A. Zaytseva, M. M. Chunkov, K. Z. Omarov}

Klevezal G. A. Dynamics of Incisor Growth and Daily Increments on the Incisor Surface in Three Species of Small Rodents. Biology Bulletin, 2010, vol. 37, no. 8, pp. 836-845.

Klevezal G. A., Lobkov V. A. Daily Increments and "Hibernation Zone" on Incisors in Ground Squirrels of the Genus Spermophilus. Zoologicheskii zhurnal, 2008, vol. 87, no. 12, pp. 1495-1503 (in Russian).

Klevezal G. A., Mina M. V. Daily layers and hibernation marks in incisor dentin of Sicista pseudonapaea and some biological remarks. Acta Theriologica, 1990, vol. 35, no. 3-4, pp. 345-356.

Klevezal G. A., Shchepotkin D. V. Incisor Growth Rate in Rodents and the Record of the Entire Annual Cycle in the Incisors of Marmota baibacina centralis. Biology Bulletin, 2012, vol. 39, no. 8, pp. 684-691.

Klevezal G. A., Shchepotkin D. V. Daily Increments on the Surface of Incisors in Rodents. Intra- and Interspecific Variations Ability. Biology Bulletin, 2017, vol. 44, no. 9, pp. 1111-1122.

Klevezal G. A., Sukhovskaya L. I. Dentin of the Rodents' Incisors as Registration Structure. Zoologicheskii zhurnal, 1995, vol. 74, no. 4, pp. 124-131 (in Russian).

Klevezal G. A., Ushakova M. V., Chunkov M. M., Feoktistova N. Yu., Surov A. V. A Record of Hibernation on the Surface of Incisor teeth in the Hamster Mesocricetus raddei (Nehring, 1894). Biology Bulletin, 2012, vol. 39, no. 9, pp. 752-758.

Klevezal G. A., Feoktistova N. Yu., Shchepotkin D. V., Surov A. V. Specific Features of the Record of Hibernation on the Incisor Surface in Allocricetulus hamsters. Biology Bulletin, 2015, vol. 42, no. 8, pp. 742-754.

Klevezal G. A., Chunkov M. M., Omarov K. Z., Shchepotkin D. V. The Record of Winter Hibernation on the Surface of Incisors in the Ciscaucasian hamster Mesocricetus raddei (Rodentia, Cricetidae) from Dagestan. Biology Bulletin, 2018, vol. 45, no. 9, pp. 1076-1082.

Klevezal G. A., Zaytseva E. A., Shchepotkin D. V., Feoktistova N. Yu., Chunkov M. M., Surov A. V. Is There a Record of Hibernation on the Surface of Incisors in the Common hamster (Cricetus cricetus)? Zoologicheskii zhurnal, 2020, vol. 99, no. 1, pp. 104-112 (in Russian).

Neumann K., Yigit N., Fritzsche P., Çolak E., Feoktistova N., Surov A., Michaux J. Genetic Structure of the Turkish hamster (Mesocricetus brandti). Mammalian Biology, 2017, vol. 86, pp. 84-91.

Pavlinov I. Ya. A Short Guidebook for Terrestrial Mammals of Russia. Moscow, Moscow University Press, 2002. 165 pp. (in Russian).

Petrovskii D. V., Novikov E. A., Moshkin M. P. Dynamics of Body Temperature in the Northern Mole Vole Ellobius talpinus (Rodentia, Cricetidae) in the Winter Period. Zoologicheskii zhurnal, 2008, vol. 87, no. 12, pp. 1504-1508 (in Russian).

Rinaldi C. A Record of Hibernation in the Incisor Teeth of Recent and Fossil Marmots (Marmota flaviventris). Proceedings of 11th International Symposium on Dental Morphology. Oulu, Finland, Oulu University Press, 1999, pp. 112-119.

Surov A. V., Zaytseva E. A., Kuptsov A. V., Katzman E. A., Bogomolov P. L., Sayan A. S., Potashnikova E. V., Tovpinetz N. N., Kuznetsova E. V., Tsellarius A. Y., Feoktistova N. Y. Circle of Life: The Common Hamster (Cricetus cricetus) Adaptations to the Urban Environment. Integrative Zoology, 2019, vol. 14, iss. 4, pp. 383-395.

Yigit N., Çolak E., Gattermann R., Neumann K., Özkurt S., Gharkheloo M. M., Fritzsche P., Çolak R. Morphological and Biometrical Comparisons of Mesocricetus Nehring, 1898 (Mammalia: Rodentia) Species Distributed in the Palaearctic Region. Turkish J. of Zoology, 2006, vol. 30, no. 3, pp. 291-299. 


\title{
HIBERNATION RECORDS ON THE INCISOR SURFACE
}

удК 599.323.42(470.67)

\section{«ЗАПИСЬ СПЯЧКИ» НА ПОВЕРХНОСТИ РЕЗЦОВ У ХОМЯКА БРАНДТА (MESOCRICETUS BRANDTI) (RODENTIA, CRICETIDAE)}

\author{
Е. А. Зайцева ${ }^{1}$, М. М. Чунков ${ }^{2}$, К. З. Омаров ${ }^{2}$ \\ ${ }^{1}$ Институт проблем экологии и эволючиии им. А. Н. Северцяова РАН \\ Россия, 117071, Москва, Ленинский просп., 33 \\ ${ }^{2}$ Прикаспийский институт биологических ресурсов \\ Дагестанского Федерального научного иентра РАН \\ Россия, 367000, Махачкала, М. Гаджиева, 45 \\ E-mail: zaycevaolena@gmail.com
}

Поступила в редакцию 28.06.2019 г., после доработки 14.07.2019 г., принята 16.08.2019 г.

\begin{abstract}
Zaytseva E. A., Chunkov M. M., Omarov K. Z. Hibernation Records on the Incisor Surface in the Turkish Hamster (Mesocricetus brandti) (Rodentia, Cricetidae) [Зайцева Е. А., Чунков М. М., Омаров К. 3. «Запись спячки» на поверхности резцов у хомяка Брандта (Mesocricetus brandti) (Rodentia, Cricetidae)] // Поволжский экологический журнал. 2020. № 1. С. 44 - 51. DOI: https: https://doi.org/10.35885/1684-7318-2020-1-44-51
\end{abstract}

Для установления соответствия «записи спячки» на поверхность резцов и данных термонакопителя исследованы зубы взрослой самки хомяка Брандта (Mesocricetus brandti), которая перезимовала в полуестественных условиях. Самка провела зиму в самостоятельно вырытой норе внутри зимовочного короба с октября 2018 по май 2019 г. Зверьку внутрибрюшинно был имплантирован термонакопитель, фиксирующий температуру тела с интервалом 20 мин. Регулярные бауты спячки отмечались с середины октября. При этом длительность периодов гипотермии увеличивалась, а минимальная температура тела снижалась, достигая минимальных значений в марте. Далее процесс шел в обратном направлении до окончания периода гетеротермии. В апикальной части резца выявлены широкие хорошо различимые приросты суточной природы, образованные до наступления периода гетеротермии. В базальной части ближе к зоне роста приросты были узкие четкие, их число в целом соответствовало количеству эпизодов нормотермии. У самого основания резца, как и в апикальной его части, опять выявлялись типичные суточные приросты. Однако корреляции длительности эпизодов нормотермии и ширины приростов не обнаружено. В отличие от хомяка Радде (Mesocricetus raddei), у которого число и характер приростов соответствовали числу и продолжительности эпизодов нормотермии в период спячки, и обыкновенного хомяка (Cricetus cricetus), у которого «зона спячки» не записывается на резцах, хомяк Брандта демонстрирует промежуточную картину, что мы объясняем различиями в условиях зимовки данных видов.

Ключевые слова: гипотермия, Mesocricetus brandti, борозды на резце, накопитель данных температуры тела.

DOI: https://doi.org/10.35885/1684-7318-2020-1-44-51 